\title{
Edirne Koşullarında Farklı Azot Dozu Uygulamalarının Sorgum x Sudan Otu (Sorghum bicolor (L.) Moench $x$ Sorghum sudanense (Piper) Stapf) Melez Çeşitlerinin Verim ve Bazı Kalite Özelliklerine Etkileri
}

Araştırma, Edirne ilinde ekilen sorgum x sudan otu melez çeşitlerine uygulanan farklı azot dozlarının erken dönemde yapılan biçimden elde edilen verim ve bazı kalite özelliklerine etkisinin belirlenmesi amacıyla yapılmıştır. Edirne ili Havsa ilçesi Musulca Köyü'nün sulanabilen çiftçi arazisinde 2014 yılında yapılan çalışma Tesadüf Blokları Faktöriyel Deneme Desenine göre 4 tekrarlamalı olarak yürütülmüştür. Farklı azot dozları $(0,4$, $8,12,16 \mathrm{~kg} / \mathrm{da}$ ) ve sorgum $\mathrm{x}$ sudan otu melez çeşitlerinin (Greengo and Sugar Graze II) yaprak sayısı, yaprak/sap oranı, sap çapı, toplam yeşil ve kuru ot verimi, ham protein oranı, toplam protein verimi, ham selüloz, ADF ve NDF oranlarını önemli ölçüde etkilediği saptanmıştır. Uygulanan azot miktarının artışı ile bitkide yaprak sayısı, sap çapı, toplam yeşil ve kuru ot verimi, ham protein oranı ve toplam protein verimi artarken; ham selüloz, asit deterjanda çözünmeyen lif ve nötr deterjanda çözünmeyen lif oranları ise düşmüştür. Azotlu gübreleme yapılmadığında, Greengo çeşidinin toplam yeşil $(1585.60 \mathrm{~kg} / \mathrm{da})$ ve kuru ot $(528.70 \mathrm{~kg} / \mathrm{da})$ verimleri ile toplam ham protein verimi $(58.16 \mathrm{~kg} / \mathrm{da})$ en düşük saptanmıştır. Ham selüloz, asit deterjanda çözünmeyen lif ve nötr deterjanda çözünmeyen lif oranları ise dekara uygulanan saf azot miktarının artmasıyla düşmüştür. Çalışmadan elde edilen sonuçlar topluca irdelendiğinde; Trakya yöresinin farklı lokasyonlarında daha uzun süreli çalışmaların yapılmasının gerektiği ve yüksek verim ile kalite özellikleri bakımından Sugar Graze II çeşidinin dekara $16 \mathrm{~kg}$ saf azot uygulaması yapılarak ana ürün şeklinde yetiştirilebileceği sonucuna varılmıştır.

Anahtar Kelimeler-Azot Dozları, Kalite Özellikleri, Ot Verimi, Sorgum x Sudan Otu Melezi

1̇̇letişim: muratatalay zm@hotmail.com(https://orcid.org/0000-0003-3046-428X)

Heksagon Katı Atık Yönetimi San. ve Tic. A.Ş, İstanbul

2*Sorumlu yazar iletișim: ertan_ates@hotmail.com.com (https://orcid.org/0000-0002-3048-497X)

Tarla Bitkileri Bölümü, Tekirdağ Namık Kemal Üniversitesi, Ziraat Fakültesi, Süleymanpaşa, Tekirdăg 


\title{
Effect of Different Nitrogen Doses on Yield and Some Quality Properties in Sorghum x Sudan Grass Hybrid (Sorghum bicolor (L.) Moench x Sorghum sudanense (Piper) Stapf) Cultivars under Edirne Ecological Conditions
}

\begin{abstract}
The aim of this investigation was to determine the effect of different nitrogen doses on yield and some quality properties of sorghum x Sudan grass hybrids (Sorghum bicolor (L.) Moench x Sorgum sudanense (Piper) Stapf) cultivars (Greengo and Sugar Graze II) in Musulca village-Edirne ecological conditions in 2014. The experiment was laid out in a two-factor factorial in randomized complete block design with four replicates. The different nitrogen doses $\left(0,4,8,12,16 \mathrm{~kg} \mathrm{da}^{-1}\right)$ and cultivars (Greengo and Sugar Graze II) affected the leaves/plant, leaf/stem ratio, total green fodder yield, total hay yield and neutral detergent fiber ratio. Contrary to crude fiber ratio, acid detergent fiber and neutral detergent fiber; the stem diameter, the leaves/plant, leaf/stem ratio, total green fodder yield, total hay yield, crude protein ratio and total protein yield increased depending on the nitrogen doses. In cv. Greengo, total green fodder, hay and protein yields were $1585.60 \mathrm{~kg} \mathrm{da}^{-1}, 528.70 \mathrm{~kg} \mathrm{da}^{-1}$ and 58.16 $\mathrm{kg} \mathrm{da}^{-1}$, respectively, by not applying nitrogen. The nitrogen application at the rate of $16 \mathrm{~kg} \mathrm{da}^{-1}$ significantly decreased crude fiber (28.03-29.20\%) and neutral detergent fiber (57.27\%) over control. According to results, cultivation of the cv. Sugar Graze II for higher forage yield and quality at the $16 \mathrm{~kg} \mathrm{da}^{-1}$ application is recommended in Edirne province and similar ecological conditions.
\end{abstract}

Keywords- Nitrogen Doses, Quality Traits, Forage Yield, Sorghum x Sudan Grass Hybrid 


\section{GİRIŞ}

Marmara Bölgesi'nin Trakya kesimi hayvancılık potansiyelinin yüksek olduğu bölgeler arasında yer almaktadır. Trakya yöresi yüz ölçümünün \% 55'i tarım arazisi, \% 24'ü orman, \% 10'u çayır-mera arazisi, \% 11'i tarıma elverişsiz arazilerden oluşmaktadır [1]. Yörede tarımsal üretimin gerçekleştiği toplam arazi varlığının yaklaşık \% 4'ünde yem bitkileri yetiştiriciliği yapılmakta ve ekim alanı olarak 428410 dekar alanda kaba yem üretimi gerçekleşmektedir. Hayvancılık potansiyelinin yüksek olduğu bu yörede hayvan varlı̆̆ı 1.4 milyon büyükbaş hayvan birimi (BBHB) civarında olup [2], bu hayvanların kaliteli kaba yem ihtiyaçları mevcut yem bitkileri yetiştiriciliği ile karşılanamamaktadır. Gerek yurdumuzun tamamında gerekse de Trakya yöresinde yem bitkileri ekim alanları artırılmalı, mevcut ekiliş ve üretime verilen desteklemelerin kesintisiz sürdürülmesi, hayvan sayısı ile hayvansal üretimin artmasına yönelik olarak ta süt desteklemelerinin $\mathrm{AB}$ ve $\mathrm{ABD}$ seviyelerinde sağlanması gerekmektedir. Bununla birlikte, ekim nöbeti sistemleri içerisinde de arzu edilen oranda yem bitkileri ekim alanına ulaşılamamışsa da bugün 1.9 milyon hektara [3] çıkan yem bitkileri ekilişi (kaba yem üretimi için hasat edilen tahıllar hariç) umut vericidir. Bu durum, desteklemelerin devam ettirilmesinin doğru olacağını göstermektedir. Yem bitkileri üretim alanlarına ait istatistiklerde daha önce yer almayan yem bitkileri yetiştiriciliklerinin [yem bezelyesi (Pisum arvense L.) vb.] başlamış olması da bunun ne kadar önemli olduğunu bir kez daha göstermektedir [4].

Yurdumuzda ve Edirne ilinde yetiştirilen ve ekim alanı artan yem bitkilerinin başında buğdaygiller (Poaceae sp.) familyasında yer alan ve sıcak iklim bitkisi olan sorgum (Sorghum bicolor (Piper) Stapf), sudan otu (Sorghum sudanense (Piper) Stapf) ile bu iki türün melezi olan çeşitler gelmektedir. Sorgum türleri ve melez çeşitleri dünyada da ekim alanı ve üretim miktarı bakımından buğday (Triticum sp.), arpa (Hordeum vulgare L.), misır (Zea mays L.) ve çeltik (Oryza sativa L.)'ten sonra en çok ekilen önemli bir yem bitkisidir. Sorgum türleri birbirleri ile kolayca melezlenerek verimli döller vermekte olup, sorgum ile sudan otunun melezlenmesi sonucunda sorgum x sudan otu melezi elde edilmiştir [5]. Bitki silaj, yeşil ve kuru ot üretimi amacıyla yetiştirilmektedir. Sorgum x sudan otu melez çeşitleri sudan otu ve sorguma ait çeşitlere göre daha verimli olup ot kaliteleri daha yüksektir [6]. Ayrıca, biçimden sonra yapılacak sulama ve gübrelemeyle hızlı şekilde yeniden büyümesi, kaba yem üretiminin yüksek olması, orta derecede tuzluluğa dayanıklı ve mısıra göre toprak seçiciliğinin az ve kurağa dayanıklılığının yüksek olması ile fazla miktarda kardeş meydana getirmesi bitkiyi sorgum ve sudan otuna göre daha tercih edilir hale getirmiştir. Edirne ilinde hayvancılık yapan çiftçiler ile işletmeler, gereksinimleri olan kaba yemi karşılamaya yönelik olarak hamur olum döneminde biçtikleri sorgum $\mathrm{x}$ sudan otu melez çeşitlerini silaj üretiminde ve çiçek salkımının oluşmaya başladığı dönemde de ot üretimi amacıyla bitkiden yararlandıkları gibi bitkinin yaklaşı 0.8-1.2 m arasında olduğu erken dönemde biçim yaparak ta hayvanların günlük yeşil ot ile kuru ot ihtiyaçlarını karşılamaya çalışmaktadırlar.

Bunun yanında, yöredeki sorgum x sudan otu melezi eken yetiştiricilerin verimi çok fazla artırdığını düşünerek yüksek dozlarda azotlu gübreleme yaptıkları da gözlenmiştir. Azotlu gübrelemenin sorgum tür ve melezlerinde verim ve kaliteyi artırdığı bilinmektedir. Ancak; ot üretimi, otlatma ve silaj gibi yararlanma amacına, iklim ve toprak koşulları ile bitki çeşidine göre uygulanan azotlu gübre miktarı ve uygulama şekli değişebilmektedir. Ayrıca; Trakya'da yaygın olarak yetiştirilmeye başlanan sorgum x sudan otu melez çeşitlerinin tarımsal özellikleri ile bu çeşitlerin yetiştiriciliklerinde uygulanabilecek yeterli azot dozları hakkında ve erken dönemdeki biçimden elde edilen otların yem değerleri konusunda yeterli çalışma da bulunmamaktadır. $\mathrm{Bu}$ bahsedilen konuların aydınlatılması ve yöre yetiştiricilerine doğru bilginin verilmesi planlanarak; araştırma, Edirne ilinde yaygın olarak ekilen ve ot üretimi amacıyla erken dönemde biçilen iki sorgum x sudan otu melez çeşidine uygulanan farklı azot dozlarının ot verimi ile bazı kalite özelliklerine etkisinin belirlenmesi amacıyla yapılmıştır.

\section{MATERYAL METOT}

Edirne ili Havsa ilçesi Musulca köyü ekolojik koşullarında sulanabilen tarım arazisinde yürütülen araştırmada, Ulusoy Tohumculuk şirketinden temin edilen iki farklı (Greengo ve Sugar Graze II) sorgum x sudan otu melez çeşidi materyal olarak kullanılmıştır. Toros Gübre firmasına ait \% 33'lük amonyum nitrat $\left(\mathrm{NH}_{4} \mathrm{NO}_{3}\right)$, Gübretaş firmasına ait \% 21'lik amonyum sülfat $\left[\left(\mathrm{NH}_{4}\right)_{2} \mathrm{SO}_{4}\right]$ ile \% 43 'lük triplesüperfosfat (TSP) $\left[\mathrm{Ca}\left(\mathrm{H}_{2} \mathrm{PO}_{4}\right) 2 . \mathrm{H}_{2} \mathrm{O}\right]$ gübrelemede kullanılmıştır. Denemenin kurulduğu tarla deniz seviyesinden $106 \mathrm{~m}$ yükseklikte olup $41^{\circ} 40^{\prime} 10 \mathrm{~N}$ kuzey enlemi ile $26^{\circ} 51^{\prime}$ 54E doğu boylamlarının kesiştiği yerde bulunmaktadır. 
Çalışmanın yapıldığı yere ait iklim verileri Tablo 1'de, toprak özellikleri de Tablo 2'de sunulmuştur. Toprak analizleri Edirne Ticaret Borsası Toprak Analiz Laboratuvarında yapılmış, iklim verileri Edirne Meteoroloji istasyonundan temin edilmiştir.

Tesadüf blokları faktöriyel deneme desenine göre 4 tekrarlamalı olarak 2014 yılında kurulan denemede her parsel $5 \mathrm{~m}$ uzunluğunda ve sıra arası $35 \mathrm{~cm}$ [6] olacak şekilde 6 sıradan oluşmuştur. Toprak analiz sonuçlarına göre, dekara saf $7 \mathrm{~kg} \mathrm{P}_{2} \mathrm{O}_{5}$ gelecek şekilde her parsel için \% 43'lük TSP'tan hesaplanan fosforlu gübre miktarları ekimle birlikte banda verilmiştir. Silaj üretimi amacıyla dekara 5-6 kg tohumluk kullanırken [7], ot üretimi amacıyla biçilen bitki saplarının kabalaşmaması için tohumluk miktarı artırılarak [8] ekim normu 8 $\mathrm{kg} / \mathrm{da}$ olacak şekilde tavlı toprağa elle ekim Mayıs ayında gerçekleştirilmiştir [9]. Ekimden sonra merdane çekilmiştir.

Tablo 1. Araştırma yürütüldüğü aylara ait Edirne ilinin bazı iklim verileri

\begin{tabular}{|c|c|c|c|c|c|c|}
\hline \multirow[b]{2}{*}{ Aylar } & \multicolumn{2}{|c|}{ Yağıș (mm) } & \multicolumn{2}{|c|}{ Sicaklık ( $\left.{ }^{\circ} \mathrm{C}\right)$} & \multicolumn{2}{|c|}{$\operatorname{Nem}(\%)$} \\
\hline & Uzun yıllar & 2014 & Uzun yıllar & 2014 & Uzun yıllar & 2014 \\
\hline Mayıs & 53.3 & 53.4 & 18.1 & 24.6 & 78.0 & 79.8 \\
\hline Haziran & 46.5 & 45.7 & 22.4 & 29.1 & 75.0 & 74.3 \\
\hline Temmuz & 32.3 & 32.1 & 24.8 & 31.7 & 68.4 & 66.2 \\
\hline Ağustos & 22.4 & 22.8 & 24.4 & 31.6 & 65.4 & 61.6 \\
\hline Eylül & 37.2 & 37.0 & 19.9 & 27.2 & 77.0 & 69.9 \\
\hline Ekim & 57.7 & 56.4 & 14.2 & 20.4 & 78.2 & 77.7 \\
\hline Ortalama & & & 20.63 & 27.4 & 73.6 & 71.5 \\
\hline Toplam & 249.4 & 247.4 & & & & \\
\hline
\end{tabular}

Tablo 2. Deneme alanı topraklarının bazı fiziksel ve kimyasal özellikleri

\begin{tabular}{llll}
\hline Özellikler & Sonuç & Birim & Değerlendirme \\
\hline Bünye & 46 & & Tinlı \\
Organik Madde & 0.15 & $\%$ & Çok Az \\
Tuz $\left(\right.$ mmhos/cm) $_{\text {Kireç }\left(\mathrm{CaCO}_{3}\right)}$ & 0.04 & $\%$ & Tuzluluk Tehlikesi Yok \\
Toplam Azot $(\mathrm{N})$ & 0 & $\%$ & Az Kireçli \\
Fosfor $(\mathrm{P})$ & 0.01 & $\%$ & Çok Az \\
Potasyum $(\mathrm{K})$ & 0.95 & $\mathrm{ppm}$ & Çok Az \\
Kalsiyum $(\mathrm{Ca})$ & 132.38 & $\mathrm{ppm}$ & Iyi \\
Magnezyum $(\mathrm{Mg})$ & 1328 & $\mathrm{ppm}$ & $\mathrm{Az}$ \\
Demir $(\mathrm{Fe})$ & 501.56 & $\mathrm{ppm}$ & Fazla \\
Bakır $(\mathrm{Cu})$ & 28.25 & $\mathrm{ppm}$ & Yeterli \\
Çinko $(\mathrm{Zn})$ & 1.03 & $\mathrm{ppm}$ & Yeterli \\
Mangan $(\mathrm{Mn})$ & 0.38 & $\mathrm{ppm}$ & $\mathrm{Az}$ \\
\hline
\end{tabular}

Dekara 4, 8, 12 ve $16 \mathrm{~kg}$ saf azot gelecek şekilde gübrenin yarısı ekimle birlikte \% 21'lik amonyum sülfat gübresinden parsel boyutlarına göre hesaplanarak elle atılmıştır. Azot dozlarının kalan yarısı bitkiler 30-35 $\mathrm{cm}$ boya ulaştığında \% 33'lük amonyum nitrat gübresi kullanılarak tamamlanmıştır. Kontrol $(0 \mathrm{~kg} / \mathrm{da}$ azot $)$ parsellerinde yalnız fosforlu gübreleme yapılmıştır. Bitkilerin ihtiyaç duyduğu dönemlerde yağmurlama sistemiyle sulama sabah saatlerinde yapılmıştır. Yabancı bitkilerle elle çapalama yöntemiyle mücadele edilmiştir. Bitkiler 100-120 cm boya geldiğinde [6,9,10,11] her parselden rastgele seçilen 10 bitkide kardeş sayısı ve bitkide yaprak sayısı bulunmuş ve parsel kenarlarından birer sıra ile parsel başlarından $35 \mathrm{~cm}$ 'lik kısımlar kenar tesiri olarak çıkarıldıktan sonra toprak seviyesinden $10 \mathrm{~cm}$ yükseklikten biçilerek [11] parsellerin yeşil ot verimleri belirlenmiştir. Rastgele seçilen bu bitkilerin yaprakları saplardan ayrıldıktan sonra ayrı ayrı tartılmış ve yaprak ağırlığı ile sap ağırlığı birbirine oranlanarak yaprak/sap oranı saptanmış [12], 3. ve 4. boğum araları elektronik kumpasla ölçülerek te sap çapı $(\mathrm{cm})$ tespit edilmiştir [13]. İlk biçimden sonra yapılan 2 . ve 3. biçimlerde de aynı azot dozları \% 33'lük amonyum nitrat gübresi kullanılarak yarısı biçimden sonra diğer yarısı da bitkiler 30-35 cm boylandığında uygulanmıştır. Her biçimden sonra daha önce belirtildiği şekilde sulama uygulamaları gerçekleştirilmiştir. Üç biçimden alınan yeşil ot verimlerinden çeşitlerin toplam yeşil ot verimi (kg/da) hesaplanmıştır. Yeşil ot örneklerinden yaklaşık $1 \mathrm{~kg}$ alınmış ve $55^{\circ} \mathrm{C}$ ' de 48 saat kurutulup 1 gün oda sicaklığında bekletildikten sonra tartılarak kuru ot verimi $(\mathrm{kg} / \mathrm{da})$ bulunmuştur [14]. Ham protein oranı $(\%)$ 
mikro-Kjeldahl yöntemiyle saptanmış ve daha sonra kuru ot verimlerinden yararlanılarak toplam ham protein verimi (kg/da) hesaplanmıştır [15]. Weende yöntemi kullanılarak ham selüloz oranı (\%) tespit edilmiş [16], asit deterjanda çözünmeyen lif (ADF) ve nötr deterjanda çözünmeyen lif (NDF) oranları ise Goering ve Van Soest [17]' in belirttikleri yöntemle ANKOM 200 lif analiz cihazı ile saptanmıştır. Çalışmadan elde edilen sonuçlar TOTEM-STAT istatistik programı kullanılarak analiz edilmiştir [18].

\section{BULGULAR VE TARTIŞMA}

Araştırmadan elde edilen sonuçlar aşağıda verilmiştir (Tablo 3). Azot dozu uygulamaları ve çeşitler ile azot dozu $\mathrm{x}$ çeşit interaksiyonları arasında bitkide kardeş sayısı bakımından istatistiksel olarak fark belirlenmemiş ve bitkide kardeş sayısı 3.93-4.10 adet arasında değişmiştir ( $\mathrm{P}>0.05)$. Yüksel [19] farklı azot dozu uygulamalarında kardeş sayısını 4.27 adet olarak tespit ederken, Başaran [20] sorgum ve sorgum x sudan otu melez çeşitlerinde kardeş sayısını 2.49 adet olarak saptamıştır. Uygulanan azot dozları bitkide yaprak sayısın ve sap çapını artırırken, yaprak/sap oranını düşürmüştür. Bitkide yaprak sayısı $16 \mathrm{~kg} / \mathrm{da}$ azot uygulamasında en fazla (8.00 adet) belirlenirken, aynı azot dozunda en düşük yaprak/sap oranı (0.37) tespit edilmiştir. Sap çapı $(1.20 \mathrm{~cm})$ iki çeşitte de $16 \mathrm{~kg} / \mathrm{da}$ azot dozunda en fazladır. Greengo çeşidinin en yüksek yaprak/sap oranı $(0.58)$ ve bitkide yaprak sayısına (7.53 adet) sahip olduğu bulunmuştur. Araştırmada azot dozu artışıyla sap çapı ve yaprak sayısı artarken, yaprak/sap oranının düşmesi biçimin yapıldığı vejetatif büyümenin hızlı olduğu genç dönemde fotosentez ürünü olarak daha sonraki büyümede kullanılabilecek olan yapısal olmayan karbonhidratların saplardaki birikiminden kaynaklanmış olabileceği söylenebilir. Azot dozu artışıly, çalışmada saptanan yapısal karbonhidratların (ham selüloz, ADF ve NDF) oranlarının düşüklüğü bunu desteklemektedir. Kardeş sayısı değerleri, Yüksel [19]' in belirlediği değerlerden düşük bulunurken, Başaran [20]'ın sonuçlarından yüksektir. Medina Lucia ve ark. [21] ile Turgut ve ark. [22] farklı azot dozu uygulamalarının bitkide yaprak sayısını etkilemediğini belirlemişlerdir. Aslan [23] sorgum x sudan otu melez çeşitlerinde yaprak sayısını 9.399.63 adet olarak tespit etmiştir. Acar ve Yıldırım [24] Konya koşullarında yürüttükleri araştırmada, bitkide yaprak sayısını 7.80 adet belirlerlerken; Acar ve ark. [25] yaprak sayısını 8.99 adet, yaprak/sap oranını 0.337 olarak saptamışlardır. Güneş ve Acar [26] yaprak sayısını 8.46-11.06 adet arasında değiştiğini bulurlarken; Yüksel [19] farklı azot dozu uygulamalarının verim ve kalite ölçütleri üzerine etkisini incelediği araştırmada yaprak sayısını 9.20 adet olarak belirlemiştir. Miko ve Manga [27] bitkide yaprak sayısının 12.30-26.00 adet arasında değiştiğini ifade ederlerken; Başaran [20] bitkide yaprak sayısını 11.40 adet tespit etmiş; Özkurt [28] yaprak sayısını ortalama 8.40 adet olarak belirlemiştir. Baytekin ve ark. [29] dekara $10 \mathrm{~kg}$ saf azot uygulamasında silajlık sorgumun yaprak/sap oranını 0.239 olarak tespit etmişlerdir. Manga ve ark. [30] sorgum x sudan otu melez çeşitlerinde sap çapının 2 cm'den 4-5 cm'ye kadar değişebileceğini söylerlerken, İptaş ve Yılmaz [31] sap çapını $1.70 \mathrm{~cm}$ olarak saptamışlardır. Yaprak sayısına ait sonuçlar, Medina Lucia ve ark. [21] ile Turgut ve ark. [22]'nın sonuçlarından farklıyken; Miko ve Manga [27]'nın buldukları değerlerden düşük, diğer araştırıcıların saptadıkları bulgular ile benzerlik göstermiştir. Yaprak/sap oranı değerleri Baytekin ve ark. [29] ile Acar ve ark. [25]'nın sonuçlarından yüksektir.

Azot dozlarının artışıyla toplam yeşil ve kuru ot verimleri ile ham protein oranı ve ham protein verimi de artmış, ham selüloz, ADF ve NDF oranları ise düşmüştür $(\mathrm{P}<0.01)$. En yüksek toplam yeşil $(13618.40 \mathrm{~kg} / \mathrm{da})$ ve kuru ot verimi (4542.30 kg/da) ile ham protein verimi $(637.42 \mathrm{~kg} / \mathrm{da})$ Sugar Graze II çeşidinde $16 \mathrm{~kg} / \mathrm{da}$ azot uygulamasından elde edilmiştir. Aynı azot dozu uygulamasında, her iki sorgum x sudan otu melez çeşidinde en düşük ham selüloz (\% 28.03-29.20) ve NDF (\% 57.27) oranları tespit edilmiştir. Ham protein ile ADF oranları çeşit ve çeşit $\mathrm{x}$ azot dozu interaksiyonundan etkilenmezken; azot dozu uygulamalarından etkilenmiştir. En yüksek ham protein oranı (\% 14.08) ve en düşük ADF oranı (\% 29.23) 16 kg/da azot dozu uygulamasında saptanmıştır. 


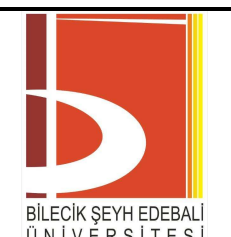

BŞEÜ Fen Bilimleri Dergisi

7(1), 221-230, 2020

BSEU Journal of Science

DOI: 10.35193/bseufbd.715571

NIVERSITESI

e-ISSN: 2458-7575 (http://dergipark.gov.tr/bseufbd)

Tablo 3. Farklı azot dozu uygulamalarının iki farklı sorgum x sudan otu melez çeşidinin bazı morfolojik ve tarımsal özelliklerine etkisi

\begin{tabular}{|c|c|c|c|c|c|c|c|}
\hline \multirow[b]{2}{*}{ Karakterler } & \multirow[b]{2}{*}{ Çeşitler } & \multicolumn{5}{|c|}{ Azot Dozları } & \multirow[b]{2}{*}{ Ortalama } \\
\hline & & Kontrol (0 kg/da) & $4 \mathrm{~kg} / \mathrm{da}$ & $8 \mathrm{~kg} / \mathrm{da}$ & $12 \mathrm{~kg} / \mathrm{da}$ & $16 \mathrm{~kg} / \mathrm{da}$ & \\
\hline Bitkide kardeş & Greengo & 3.93 & 4.10 & 3.93 & 4.03 & 4.07 & 4.01 \\
\hline \multirow[t]{2}{*}{ say1s1 } & Sugar Graze II & 3.93 & 4.00 & 4.03 & 3.97 & 4.00 & 3.99 \\
\hline & Ortalama & 3.93 & 4.05 & 3.98 & 4.00 & 4.03 & 4.00 \\
\hline \multicolumn{2}{|c|}{ EKÖF (En Küçük Önemli Fark) } & Ö.D. & & & & & \\
\hline \multirow{3}{*}{$\begin{array}{l}\text { Bitkide yaprak } \\
\text { sayısı }\end{array}$} & Greengo & 7.00 & 7.00 & 7.33 & 6.67 & 8.67 & $7.53 \mathrm{a}$ \\
\hline & Sugar Graze II & 6.00 & 6.33 & 7.33 & 7.00 & 7.33 & $6.80 \mathrm{~b}$ \\
\hline & Ortalama & $6.50 c$ & $6.67 c$ & $7.33 b$ & $7.33 b$ & $8.00 a$ & 7.17 \\
\hline \multicolumn{2}{|l|}{ EKÖF } & Çeşit (Ç): 0.41 & Azot & $(\mathrm{AD}): 0.28$ & $84 * * \quad$ Ç x AD: & & \\
\hline \multirow[t]{3}{*}{ Yaprak/sap oranı } & Greengo & 0.67 & 0.77 & 0.54 & 0.56 & 0.37 & $0.58 \mathrm{a}$ \\
\hline & Sugar Graze II & 0.50 & 0.58 & 0.35 & 0.30 & 0.37 & $0.42 b$ \\
\hline & Ortalama & $0.58 b$ & $0.67 a$ & $0.45 c$ & $0.43 c$ & $0.37 d$ & 0.50 \\
\hline \multicolumn{2}{|l|}{ EKÖF } & Ç: $0.137 * *$ & \multicolumn{2}{|c|}{ AD: $0.085^{* *}$} & Ç x AD: Ö.D. & & \\
\hline \multirow[t]{3}{*}{ Sap çapı $(\mathrm{cm})$} & Greengo & $0.83 \mathrm{f}$ & $0.93 \mathrm{e}$ & $1.07 \mathrm{~d}$ & $1.17 \mathrm{~b}$ & $1.20 \mathrm{a}$ & 1.04 \\
\hline & Sugar Graze II & $0.80 \mathrm{~g}$ & $1.07 \mathrm{~d}$ & $1.07 \mathrm{~d}$ & $1.10 \mathrm{c}$ & $1.20 \mathrm{a}$ & 1.05 \\
\hline & Ortalama & $0.82 e$ & $1.00 d$ & $1.07 c$ & $1.13 b$ & $1.20 a$ & 1.045 \\
\hline \multicolumn{2}{|l|}{ EKÖF } & Ç: Ö.D. & AD: 0 & & Ç x AD: $0.027^{*}$ & & \\
\hline \multirow{3}{*}{$\begin{array}{l}\text { Yeşil ot verimi } \\
(\mathrm{kg} / \mathrm{da})\end{array}$} & Greengo & $1585.60 \mathrm{j}$ & 6387.10h & $10174.10 \mathrm{e}$ & $12347.00 \mathrm{~b}$ & $11489.90 \mathrm{c}$ & $8396.74 b$ \\
\hline & Sugar Graze II & $3172.20 \mathrm{i}$ & $7359.90 \mathrm{~g}$ & $9921.20 \mathrm{f}$ & $11192.70 \mathrm{~d}$ & $13618.40 \mathrm{a}$ & $9052.88 \mathrm{a}$ \\
\hline & Ortalama & $2378.90 e$ & $6873.50 d$ & $10047.65 c$ & $11769.85 b$ & $12554.15 a$ & 8724.81 \\
\hline \multicolumn{2}{|l|}{ EKÖF } & Ç: $411.777 * *$ & $\mathrm{AD}: 3$ & $33 * *$ & Ç x AD: 231.174 & & \\
\hline \multirow{3}{*}{$\begin{array}{l}\text { Kuru ot verimi } \\
(\mathrm{kg} / \mathrm{da})\end{array}$} & Greengo & $528.70 \mathrm{~h}$ & $2128.80 \mathrm{f}$ & $3391.00 d$ & $4115.20 \mathrm{~b}$ & $3830.30 \mathrm{c}$ & $2798.80 \mathrm{~b}$ \\
\hline & Sugar Graze II & $1059.10 \mathrm{~g}$ & $2452.70 \mathrm{e}$ & $3310.20 d$ & $3735.70 \mathrm{c}$ & $4542.30 \mathrm{a}$ & $3020.00 \mathrm{a}$ \\
\hline & Ortalama & $793.90 e$ & $2290.75 d$ & $3350.60 c$ & $3925.45 b$ & $4186.30 a$ & 2909.40 \\
\hline \multicolumn{2}{|l|}{ EKÖF } & Ç: $120.217 * *$ & \multicolumn{2}{|c|}{ AD: $173.669^{* *}$} & Ç x AD: 100.887 & & \\
\hline \multirow{3}{*}{$\begin{array}{l}\text { Ham protein } \\
\text { oranı }(\%)\end{array}$} & Greengo & 11.00 & 12.07 & 12.40 & 13.20 & 14.13 & 12.56 \\
\hline & Sugar Graze II & 11.33 & 12.17 & 12.57 & 13.50 & 14.03 & 12.72 \\
\hline & Ortalama & $11.17 e$ & $12.12 d$ & $12.48 c$ & $13.35 b$ & $14.08 a$ & 12.64 \\
\hline \multicolumn{2}{|l|}{ EKÖF } & Ç: Ö.D. & \multicolumn{2}{|c|}{ AD: $0.078 * *$} & Ç x AD: Ö.D. & & \\
\hline \multirow{3}{*}{$\begin{array}{l}\text { Ham protein } \\
\text { verimi }(\mathrm{kg} / \mathrm{da})\end{array}$} & Greengo & $58.16 \mathrm{f}$ & $256.88 \mathrm{~d}$ & $420.48 c$ & $543.21 b$ & $541.34 b$ & 455.02 \\
\hline & Sugar Graze II & $120.03 \mathrm{e}$ & $298.42 d$ & $415.99 c$ & $504.32 b$ & $637.42 \mathrm{a}$ & 494.04 \\
\hline & Ortalama & $89.09 e$ & $277.65 d$ & $418.24 c$ & $523.76 b$ & $589.38 a$ & 474.53 \\
\hline EKÖF & & Ç: Ö.D. & AD: 6 & $8 * *$ & Ç x AD: 70.111* & & \\
\hline Ham selüloz & Greengo & $31.73 \mathrm{a}$ & $30.57 \mathrm{c}$ & $30.13 \mathrm{~cd}$ & $29.83 d$ & $29.20 \mathrm{e}$ & 30.29 \\
\hline oranı $(\%)$ & Sugar Graze II & $32.03 \mathrm{a}$ & $31.53 b$ & $30.80 \mathrm{c}$ & 29.53de & $28.03 \mathrm{e}$ & 30.39 \\
\hline & Ortalama & $31.83 a$ & $31.05 b$ & $30.47 c$ & $29.68 c$ & $28.62 d$ & 30.34 \\
\hline EKÖF & & Ç: Ö.D. & AD: 0 & & Ç x AD: $0.497 * *$ & & \\
\hline ADF oranı (\%) & Greengo & 35.87 & 35.07 & 33.77 & 31.40 & 29.33 & 33.09 \\
\hline & Sugar Graze II & 36.77 & 35.07 & 33.30 & 31.30 & 29.13 & 33.11 \\
\hline & Ortalama & $36.32 a$ & $35.07 b$ & $33.53 c$ & $31.35 d$ & $29.23 e$ & 33.10 \\
\hline EKÖF & & Ç: Ö.D. & AD: 0 & & Ç x AD: Ö.D. & & \\
\hline NDF oranı (\%) & Greengo & $64.70 \mathrm{~b}$ & $63.37 \mathrm{c}$ & $61.30 \mathrm{e}$ & $59.17 \mathrm{~g}$ & $57.27 \mathrm{~h}$ & $61.16 b$ \\
\hline & Sugar Graze II & $65.53 \mathrm{a}$ & $64.17 b$ & $62.33 \mathrm{~d}$ & $59.73 \mathrm{f}$ & $57.27 \mathrm{~h}$ & $61,81 \mathrm{a}$ \\
\hline & Ortalama & $65.12 a$ & $63.77 b$ & $61.82 c$ & $59.45 d$ & $57.27 e$ & 61.48 \\
\hline EKÖF & & Ç: $0.533^{* *}$ & AD: 0 & & Ç x AD: $0.657^{* *}$ & & \\
\hline
\end{tabular}

Ö.D.: Önemli Değil (P>0.05, 0.01), *: $\mathrm{P}<0.05, * *: \mathrm{P}<0.01$

Bitki hücrelerindeki karbon (C) içeren maddelerle birleşen azot klorofilin yapıtaşı olup fotosentez gibi fizyolojik olaylarda görev almakta; amidler, aminoasitler, flavonoidler, vitaminler ve diğer organik maddeleri meydana getirerek bitki büyüme ve gelişiminde de önemli bir makro elementtir. Ayrıca, yapılan azotlu gübrelemeyle bitkide daha fazla protein birikimi sağlandığı da bilinmektedir. Çeşit, biçim sıklığı ve yüksekliği ile toprak ve iklim özellikleri sorgum tür ve melezlerinde uygulanacak azot dozu ve uygulama şekliyle yakından ilgilidir [32]. Sugar Graze II çeşidine uygulanan $16 \mathrm{~kg} / \mathrm{da}$ azot dozunun yeşil ve kuru ot verimi ile bazı kalite özellikleri bakımından en uygun doz olduğunun ortaya çıkması, yörede bu çeşidin üç biçimli sistemde azot ihtiyacının ne olduğunu göstermesi bakımından önemlidir. Sorgum x sudan otu melezinde azotlu gübreleme ve biçim yüksekliğinin verim ve kaliteye etkisini araştıran İptaş ve ark. [32], dört farklı azot dozu uygulamışlar ve bitki 100-120 cm boya geldiğinde farklı biçim yüksekliklerinde yılda üç biçim yapmışlardır. Araştırıcılar, bitkinin yeşil ve kuru madde verimlerini sırasıyla $11558.7-14860.9 \mathrm{~kg} / \mathrm{da}$ ve $2296.0-2879.8 \mathrm{~kg} / \mathrm{da}$ olarak tespit etmişlerdir. Yılmaz ve Sağlamtimur [33] ile Sarkar [34] en yüksek yeşil ot verimini $15 \mathrm{~kg} / \mathrm{da}$ azot dozu uygulamasında belirlerken, Arslangiray [35] $18 \mathrm{~kg} / \mathrm{da}$ azot dozu uygulamasında yeşil ot verimini en fazla 
bulmuştur. Araştırmadan elde edilen yeşil ve kuru ot verimlerine ait sonuçlar daha önce yapılan bu çalışmalarla benzerlik göstermektedir. Uzun ve Çiğdem [36], Carmi ve ark. [37] ve Nazlı [38] sorgum ve sorgum x sudan otu melez çeşitlerinin NDF oranlarının \% 61.24-68.30 arasında değiştiğini saptamışlardır. Yüksel [19], sorgum x sudan otu melez çeşidinde farklı azot dozu uygulamalarının ham selüloz oranına etkisinin önemsiz olduğunu belirtirken, Chattha ve ark. [39] sorgumda \% 20.10-32.00 ham selüloz tespit etmişlerdir. Torrecillas ve ark. [40] sorgumda ham protein oranını oldukça düşük (\% 4.00-4.20) bulmuşlardır. Khaleduzzaman ve ark. [41], Tosunoğlu ve Mut [42] ve Mut ve ark. [10] kuru ot verimlerini sırasıyla 536-589 kg/da, 609,50-1183 kg/da ve $767-831 \mathrm{~kg} / \mathrm{da}$ olarak saptamışlardır. Sorgum ve sorgum x sudan otu melez çeşitlerinin ADF oranlarını Nazlı ve ark. [43] ve Özkurt [28] sirasiyla \% 34.00 ve \% 40.6940 .10 olarak bildirmektedirler.

\section{SONUÇLAR}

Edirne ili ve benzer iklim özelliklerine sahip bölgelerin farklı lokasyonlarında daha uzun süreli çalışmaların yapılmasının gerektiği ve yüksek verim ile kalite özellikleri bakımından Sugar Graze II çeşidinin dekara $16 \mathrm{~kg}$ saf azot uygulaması yapılarak ana ürün şeklinde yetiştirilebileceği sonucuna varılmıştır.

\section{TEŞEKKÜR}

Bu makale 2019 yılında Tekirdağ Namık Kemal Üniversitesi Fen Bilimleri Enstitüsü tarafından kabul edilmiş olan Murat ATALAY'ın Yüksek Lisans tezinin bir bölümüdür.

\section{KAYNAKLAR}

[1] Yüksel, A. N. (2013). Orman ve Su Kaynaklarl, Özel İhtisas Komisyonu Raporu. https://www.trakyaka.org.tr/upload/Domain/trakyaka/28062013NJ-TY.pdf, (21.07.2017).

[2] Türkiye İstatistik Kurumu. (2017). $2017 \quad$ Bölgesel Istatistikler. https://biruni.tuik.gov.tr/bolgeselistatistik/tabloOlustur.do.

[3] Meşe, A., Gülümser, E. \& Mut, H. (2019). Bilecik ili yem bitkilerinin mevcut durumu. BŞEÜ Fen Bilimleri Dergisi, 6, 336-343.

[4] Ateş, E., \& Tekeli, A. S. (2017). Farklı taban gübresi uygulamalarının yem bezelyesi (Pisum arvense L.)'nin ot verimi ve kalitesine etkisi. KSÜ Doğa Bilimleri Dergisi, 20, 13-16.

[5] Skerman, P. J., \& Riveros, F. (2017). Tropical Grasses. FAO Plant Production and Protection Series No. 23, Rome.

[6] Avcioğlu, R., Geren, H., \& Kavut, Y. T. (2009). Sorgum Sudan otu Sorgum x Sudan otu Melezi. Yem bitkileri Buğdaygil ve Diğer familyalardan Yem Bitkileri, Ed: Avcıŏ̆lu, R., Hatipoğlu, R. \& Karadağ, Y., T.C. Tarım ve Köyişleri Bakanlığı Tarımsal Üretim ve Geliştirme Genel Müdürlügüü, T.C. Tarım ve Köyişleri Bakanlığı Yayınları, İzmir, 680-695.

[7] Grubinger, V. (2017). Sorghum-Sudangrass: A Vlgorous Cover Crop. University of Vermont Extension, Burlington, New Jersey, ABD.

[8] Tekeli, A. S. (1988). Buğdaygil Yem Bitkileri. T.Ü Tekirdăg Ziraat Fakültesi Yayın No: 64, Ders Notu: 49, $45 \mathrm{~s}$, Tekirdă̆,

[9] Ateş, E. (2012). Sorgum x sudanotu melezi (Sorgum bicolor (L.) Moench x Sorgum sudanense (Piper) Stapf). Hasad Hayvancıllk, 28, 70-71.

[10] Mut, H., Gulumser, E., Dogrusoz, M. C., \& Basaran, U. (2017). Effect of different nitrogen levels on hay yield and some quality traits of sudan grass and sorghum x Sudan grass hybrids. Animal Nutrition and Feed Technology, 17, 269-278. 
[11] Acar, R. (1995). Sulu şartlarda ikinci ürün olarak bazı baklagil yem bitkileri ve tahıl karışımlarının yetiştirilme imkanları. Yüksek Lisans Tezi, Selçuk Üniversitesi, Fen Bilimleri Enstitüsü, Konya.

[12] Wright, B., Wheeler, T., \& McKinley, J. (2016). Forage Sorghum-Sudan Grass. Ministry of Agriculture, Food and Rural Affairs, Stone Road West, Guelph, Ontario, Canada.

[13] Ates, E. (2011). Determination of forage yield and its components in blue melilot (Melilotus caerulea (L.) Desr.) grown in the western region of Turkey. Cuban Journal of Agricultural Science, 45, 299-302.

[14] Tekeli, A. S., \& Ateş, E. (2003). Determination of some agricultural and botanical characters of some annual clovers (Trifolium sp.). Bulgarian Journal Agricultural Science, 9, 505-508.

[15] Ates, E., \& Tenikecier, H.S.(2019). Hydrocyanic acid content, forage yield and some quality features of two sorghum-Sudan grass hybrid cultivars under different nitrogen doses in Thrace, Turkey. Current Trends in Natural Sciences, 8, 55-62.

[16] Association of Official Analytical Chemists. (1990). Official Methods of Analysis. 15 ${ }^{\text {th }}$ ed., Washington DC., USA.

[17] Goering, H. K., \& Van Soest, P. J. (1970). Forage Fiber Analysis: Apparatus, Reagents, Procedures and Some Applications. Agric. Handbook No. 379. ARC, USDA, Washington DC., USA.

[18] Açıkgöz, N., İlker, E., \& Gökçöl, A. (2004). Biyolojik Araştırmaların Bilgisayarda Değerlendirilmeleri. Ege Üniversitesi TOTEM Yayın No. 2, İzmir.

[19] Yüksel, O. (2006). Sorgum x sudanotu (Sorghum bicolor (L.) Moench x Sorghum sudanense (piper) Stapf.) melezinde farklı azot dozu uygulamalarının verim ve bazı kalite özelliklerine etkileri. Yüksek Lisans Tezi, Süleyman Demirel Üniversitesi, Fen Bilimleri Enstitüsü, Isparta.

[20] Başaran, R. (2011). Bartın'da sorgum (Sorghum bicolor (L.) Moench) çeşitlerinin ikinci ürün silajlık olarak yetiştirilmesi. Yüksek Lisans Tezi, Selçuk Üniversitesi, Fen Bilimleri Enstitüsü, Konya.

[21] Medina Lucia, B., Riquelme Villagran, E. O., \& Valdez-Oyervidez, A. (1986). The effect of nitrogen and phosphorus fertilizer and population density on lowland fodder sorghum production under irrigation. Herbage Abstract, 56, 3789.

[22] Turgut, I., Bilgili, U., \& Açıkgöz, E. (2005). Production of sweet sorghum (Sorghum bicolor L. Moench) increases with increased plant densities and nitrogen fertilizer levels. Acta Agri. Scandinavica, Sec. B-Plant Soil Science, 55, 236-240.

[23] Aslan, H. (1998). Tokat ekolojik şartlarında sorgum x sudanotu melezinde farklı sira aralı̆̆ında, ekim normu ve azot dozlarının verim ve bazı agronomik özelliklere etkisi. Yüksek Lisans Tezi, Gaziosmanpaşa Üniversitesi, Fen Bilimleri Enstitüsü, Tokat.

[24] Acar, R., \& Yıldırım, A.İ. (2001). Farklı bitki sıklıklarının süpürge darısında (Sorghum vulgare var. technicum Jav.) ot verimi ve verim unsurları üzerine etkileri. Selçuk Üniversitesi Ziraat Fakültesi Dergisi, 15, 128-133.

[25] Acar, R., Akbudak, M. A., \& Sade, B. (2002). Konya ekolojik şartlarında silajlik sorgum x sudanotu melezlerinin verimleri ile verimi etkileyen bazı özelliklerin belirlenmesi. Selçuk Üniversitesi Ziraat Fakültesi Dergisi, 16, 88-95.

[26] Güneş, A., \& Acar, R. (2005). Karaman ekolojik koşullarında silajlık sorgum x sudanotu melezinin ikinci ürün olarak yetiştirme imkanlarının belirlenmesi. Selçuk Üniverisitesi Ziraat Fakültesi Dergisi, 19, 8-15.

[27] Miko, S., \& Manga, A. A. (2008). Effect of intra-spacing and nitrogen rates on growth and yield of sorghum (Sorghum bicolor L.). Production Agriculture and Technology, 4, 66-73. 
[28] Özkurt, M. (2013). Tokat ekolojik koşullarında ikinci ürün olarak yetiştirilebilecek silajık sorgum (Sorghum bicolor (L.) Moench) çeşitlerinde farklı sıra aralıklarının bazı morfolojik ve tarımsal özellikleri üzerine etkisi. Yüksek Lisans Tezi, Gaziosmanpaşa Üniversitesi, Fen Bilimleri Enstitüsü, Tokat.

[29] Baytekin, H., Gül, İ., \& Bengisu, G. (1995). Harran ovası sulu koşullarında ikinci ürün olarak yetiştirilen silaj sorgumda farklı azot dozlarının verim ve bazı tarımsal karakterlere etkisi. Harran Üniversitesi Ziraat Fakültesi Dergisi, 1, 212-226.

[30] Manga, İ., Acar, Z., \& Erden, İ. (1994). Buğdaygil Yem Bitkileri. Ondokuz Mayıs Üniversitesi Ders Notu No. 6, Samsun.

[31] İptaş, S., \& Yılmaz, M. (1995). Silajlık sorgum ve sorgum x sudanotu melezlerinde farklı sıra aralıklarının bazı morfolojik ve tarımsal özelliklere etkisi üzerine bir araştırma. Gaziosmanpaşa Üniversitesi Ziraat Fakültesi Dergisi, 12, 203-211.

[32] İptaş, S., Brohi, A.R., \& Aktaş, A. (2001). Sorgum x sudanotu melezinde (Sorghum vulgare Pers. $x$ Sorghum sudanense (Piper) Stapf.) azotlu gübreleme ve biçim yüksekliğinin verim ve kaliteye etkisi. Tarım Bilimleri Dergisi, 7, 69-74.

[33] Yılmaz, Ş., \& Sağlamtimur, T. (1997). Amik ovası koşullarında II. ürün olarak yetiştirilen sorgum x sudanotu (Sorghum bicolor $x$ Sorghum sudanense) melez çeşidinde azot gübrelemesinin ve sıra aras1 mesafenin ot verimine ve kalitesine etkisi üzerine bir araştırma. MKÜ Ziraat Fakültesi Dergisi, 2, 87-100.

[34] Sarkar, B. (2000). Effect of different doses of nitrogen fertilizer on growth, yield, chemical composition and degradability of zamboo grass. MS Thesis, Bangladesh Agricultural University, Department of Animal Nutrition, Mymensingh.

[35] Arslangiray, C. (1998). Çukurova koşullarında ikinci ürün olarak yetiştirilen bazı tane sorgum (Sorgum bicolor L.) ve sorgum x sudanotu (Sorgum sudanense L.) melez çeşitlerinde azot gübrelemesinin dane ve hasıl verimine etkisi üzerinde araştırmalar. Doktora Tezi, Çukurova Üniversitesi, Fen Bilimleri Enstitüsü, Adana.

[36] Uzun, F., \& Çiğdem, İ. (2005). Yemlik kocadarı ve kocadarı-sudan otu melezleri. OMÜ Ziraat Fakültesi Dergisi, 20, 66-72.

[37] Carmi, A., Aharoni, Y., Edelstein, M., Umiel, N., Hagiladi, A., Yosef, E., Nikbachat, M., Zenou, A., \& Miron, J. (2006). Effects of irrigation and plant density on yield, composition and in vitro digestibility of a new forage sorghum variety at two maturity stages. Animal Feed Science and Technology, 131, 121-133.

[38] Nazl1, İ.R. (2011). Sorgum x sudanotu melezi (Sorghum bicolor x Sorghum bicolor var. Sudanense) tarımında bazı organik atıkların kullanım olanakları. Yüksek Lisans Tezi, Çukurova Üniversitesi, Fen Bilimleri Enstitüsü, Adana.

[39] Chattha, M. U., Iqbal, A., Hassan, M. U., Chattha, M. B., Ishaque, W., Usman, M., Khan, S., Fayyaz, M. T., \& Ullah, M.A. (2017). Forage yield and quality of sweet sorghum as influenced by sowing methods and harvesting times. Journal of Basic \& Applied Sciences, 13, 301-306.

[40] Torrecillas, M., Cantamutto, M. A., \& Bertoia, L. M. (2011). Head and stover contribution to digestible dry matter yield on grain and dual-purpose sorghum crop. Australian Journal of Crop Science, 5, 116-122.

[41] Khaleduzzaman, A. B. M., Enamul Haq Hazary, M., Emdadul Haque, M., \& Shafiqul Islam, M. (2013). Nitrogen and phosphorus fertilization for Jumbo (Sorghum bicolor x Sorghum sudanese) forage production and evaluation by using near infrared reflectance spectroscopy. International Journal of Agronomy and Plant Production, 4, 3576-3582.

[42] Tosunoğlu, S., \& Mut, H. (2015). Yozgat Şartlarında Ana ve İkinci Ürün Olarak Yetiştirilebilecek Sorgum, Sudan Otu Ve Sorgum Sudan Otu Melez Çeşitlerinin Belirlenmesi. Türkiye 11. Tarla Bitkileri Kongresi. 710 Eylül, Çanakkale, 246. 
[43] Nazlı, İ. R., İnal, İ., Kuşvuran, A., Sezer, C.M., \& Tansı, V. (2013). Çukurova Koşullarında Bazı Sorgum x Sudanotu Melezi Çeşitlerinin Verim ve Kalite Özelliklerinin Belirlenmesi. Türkiye 10. Tarla Bitkileri Kongresi. 10-13 Eylül, Konya, 452. 